\title{
Nomophobia Levels and Personalities of University Students
}

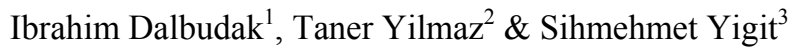 \\ ${ }^{1}$ Atabey Vocational School, Isparta University of Applied Sciences, Isparta, Turkey \\ ${ }^{2}$ Turkey Usak University Sports Science Faculty, Usak, Turkey \\ ${ }^{3}$ School of Physical Education and Sports Namik Kemal University, Tekirdag, Turkey \\ Correspondence: Ibrahim Dalbudak, Atabey Vocational School, Isparta University of Applied Sciences, Isparta, \\ Turkey. E-mail: dalbudakibo@hotmail.com
}

$\begin{aligned} & \text { Received: January 18, } 2020 \\ & \text { Accepted: February 22, } 2020 \quad \text { Online Published: March 1, } 2020 \\ & \text { doi:10.5539/jel.v9n2p166 }\end{aligned}$ URL: https://doi.org/10.5539/jel.v9n2p166

\begin{abstract}
The development of technology has made our lives easier and has caused some dependencies to enter our lives. The aim of this study is to measure the nomophobia levels of the students at the faculty of sports at Uşak University and the faculty of technology at Isparta Applied Sciences University and to examine the relationship of personality with the level of nomophobia.

The sample of the study consists of a total of 408 students at the faculty of sports at Uşak University and the faculty of technology at Isparta Applied Sciences University. Volunteering was taken into account in participation. Students' nomophobia level and personality properties were analyzed according to the gender of the participants, age groups, educational status, department, phone usage by years, daily smartphone usage time, mobile internet usage time, daily mobile internet usage time, smartphone night off status, the time spent with friends during the day.

In the study, the Nomophobia Scale, developed by Yıldırım and Correia (2015) and whose validity and reliability were made, was developed by Somer, Tatar and Korkmaz (2001) and the 5-Factor Personality Inventory, whose validity and reliability of short form were, made was used by Tatar (2005). In this study, SPSS 22.00 Program used in quantitative research methods was used. The data were summarized by giving percentage and frequency tables. This study was tested with a significance level of 0.05 . There are statistically both significant relationship $(\mathrm{p}<.05)$ and non-sense relationship $(\mathrm{p}>.05)$ between nomophobia and subscale scores according to age, gender, department, phone usage by years, daily smartphone usage time, mobile internet usage time, daily mobile internet usage time, smartphone night off status and the time spent with friends during the day. A statistically significant relationship was found between personality and nomophobia $(\mathrm{p}<.05)$.

The results of the study showed us how nomophobia is effective on students. As a result of the study, it is an indicator that personality affects nomophobia. It seems that personality is effective on nomophobia. As the personality gets stronger, the level of nomophobia will decrease. Therefore, necessary studies can be done about the personality. In addition, a new research can be proposed in which students in the other department will be assessed to be affected by the level of nomophobia.
\end{abstract}

Keywords: nomophobia, personality, university students

\section{Introduction}

Information and communication technologies have significantly changed people's lifestyle and have become an integral part of their lives (Salehan et al., 2013). The word nomophobia is a name and refers to the person with nomophobia; The word nomophobic is an adjective and it is used to describe the characteristics of the behaviors related to nomophobia (Yıldirım, 2014). Nomophobia is defined as the irrational fear and anxiety that an individual experience when they cannot access their mobile device or communicate via mobile device (King et al., 2013). Bragazzi and Del Puente (2014) defined nomophobia as a disorder experienced by the digital society, which is manifested by the discomfort, anxiety, irritability and distress that occurs when the person cannot reach the cell phone or computer. Nomophobia is the modern fear of not being able to communicate with a mobile phone or over the Internet. Nomophobia is a term that refers to a collection of behavior or symptoms related to mobile phone use (King et al., 2014). Nomophobia refers to discomfort, anxiety, irritability or pain caused by our 
inability to contact a mobile phone (Pavithara et al., 2015). Having access to the internet everywhere with smart phones, using social media and many applications and providing the opportunity to communicate quickly, increases the time that individuals spend with smartphones. In addition, the fact that many actions we routinely perform in our lives with these smartphones increase the anxiety experienced in case of inability to reach the devices due to their dependence on the devices (Yıldırım \& Correia, 2015; Y1ldırım et al., 2016). In particular, young people use their mobile phones daily to search for information, play games and communicate with others and for various purposes (Salehan et al., 2013). Placing smart phones at the center of their lives can cause a number of physical and psychological problems. The use of smartphones also reveals some undesirable effects such as addiction or restlessness (Öz \& Tortop, 2018) and causes individuals to spend a lot of money on virtual activities, have financial problems and spend time more than necessary on smartphones and disconnect the relation with social environment, academic life and business life (Beranuy et al., 2009). This will affect the life of individuals negatively.

The common origin of the term personality in foreign languages is based on the word "persona". The real meaning of the word Persona is the "mask" used by theater actors in the Latin language. It is thought that the word "Persona" is related to the Greek words "prosopon" and Etruscan "phersu" (Yanbast1, 1990). Personality can be defined as the whole of the individual's special and distinctive behavior. McCrae and Costa (1989) defined personality as an interpersonal, emotional, motivational, experience-based interaction style that explains the behaviors of the individual in different situations, or "is a unique and relatively fixed behavior, thought and emotion pattern exhibited by individuals" (Greenberg, 1999). Many theorists have different views on defining and measuring personality. It is seen from the definitions about personality that personality is consistent and has the feature that distinguishes the individual from other people (Buchanan \& Huczynski, 1997). Therefore, the personality traits are not temporary but continuous (Başaran, 2000). This shows that personality is consistent. It is seen that both hereditary and environmental features are effective in shaping the personality (Robbins, 2012). Today, it is accepted by many researchers that personality is influenced by many factors (Parikh \& Gupta, 2010).

Although the word sport has spread around the world with the help of English, it is not an English word. It was born from the word "Disportere" or "Deportere", which means distributing, separating from each other in Latin. The word used in this way was eroded over time and started to be used as "Disport". It took the form of "Sport" since 17th century. Turkish has been also influenced by the interaction of the international language and added the word "Sport" to its richness, then the word has started to be used as "sports" as it is pronounced. Today, many definitions about sports have been made. Sport is a competitive, solidarity and cultural phenomenon that develops the abilities that individual gains while transforming the natural environment into a human environment, that the individual does with or without tools under certain rules within the scope of leisure activity individually or collectively, or as a full time work (Atasoy \& Kuter, 2005). Sport is a vehicle that displays a set of goals that reveal and develop a person's own self-determination, group work, mutual aid, understanding of sincerity and honesty in his/her movements, and healthy body and soul structure (Ylldırım et al., 2006).

There are many definitions about education in the literature. Education is the sum of the processes in which the individual develops his/her abilities, attitudes and other forms of positive value in the society in which s/he lives. According to another definition, education is a social process that includes a selected and supervised environment (especially school) to achieve the individual's social ability and optimal level of personal development. One of our educators defines education as the process of creating desired change in the behavior of the individual through his/her own life and with a purpose. When we review these definitions, we understand that education is a process that helps the development of the personality and takes the individual as basis, prepares him/her to adult life, and provides the necessary knowledge, skills and behaviors (Tezcan, 1997).

The aim of this study is to measure the nomophobia levels of the students at the faculty of sports at Uşak University and the faculty of technology at Isparta Applied Sciences University and to examine the relationship of personality with the level of nomophobia.

\section{Material and Method}

In obtaining the data, the Nomophobia Scale and 5-factor personality inventory (5FKE), "Personal Information Form" prepared by the researcher on their demographic properties was used. The form consists of three sections. The first part is the personal information form of the students (age, gender, department, sports branch, usage of telofon by years, daily smartphone usage time, mobile internet usage time, daily mobile internet usage time, night-time switches off the smartphone, average time spent with friends during the day).

In the second part; Nomophobia Scale, developed by Yıldırım and Correia (2015), consists of 20 items. It is a 7-point Likert type scale that is answered from scale 1 (I strongly disagree) to 7 (I strongly agree). There are four 
sub-dimensions in the scale. These sub-dimensions are "Inability to Access Information" (4 items), "To Give Up Comfort" (5 items), "Not Communicating" (6 items) and "Losing Online Connection" (5 items) (Yildırm \& Correia, 2015). The scale was adapted into Turkish by Yıldırım et al. (2016). There are 20 items in the scale as in the original form. The sub-dimensions of the scale are "Inability to Access Information" (4 items), "To Give Up Comfort" (5 items), "Not Communicating" (6 items) and "Losing Online Connection" (5 items). The reliability coefficient for the Turkish form of the scale was calculated as .92. The reliability coefficients for the sub-dimensions are respectively $.90, .74, .94$ and .91 . In order to ensure the validity and reliability of the Turkish version of the scale, a pre-test was conducted by Yildırım et al. (2016).

In the third part, five-factor personality inventory, developed by Somer et al. (2004) and whose validity and reliability of short form was done by Tatar (2005), was used in order to determine personality traits. Five basic personality dimensions evaluate the inventory personality traits. There are items in the inventory that question the extraversion factor, the softness factor, the Self-Control factor, the Emotional Inconsistency factor, and the Openness to Development factor. These items are the features that express the emotional, behavioral and intellectual characteristics that the person evaluates himself. Inventory items consist of 85 items with 5-point Likert scale (Completely Appropriate, Slightly Appropriate, No Idea, Not Very Appropriate, Not Appropriate).

\section{Data Analysis}

\subsection{Turkish Nomophobi Scale}

\section{Reliability Statistics}

\begin{tabular}{|c|c|r|}
\hline $\begin{array}{c}\text { Cronbach's } \\
\text { Alpha }\end{array}$ & $\begin{array}{c}\text { Cronbach's } \\
\text { Alpha Based } \\
\text { on } \\
\text { Standardized } \\
\text { Items }\end{array}$ & N of ltems \\
\hline .914 & .914 & 20 \\
\hline
\end{tabular}

Figure 1. Validity and reliability of the Turkish Nomophobia Scale

Cronbach's Alpha value of the Turkish Nomophobia Scale, consisting of 20 items and applied to 408 individuals, was found to be 0.914 .

\subsubsection{Sub-Scales}

i) Inability to Access Information Subscale

Reliability Statistics

\begin{tabular}{|c|c|c|}
\hline $\begin{array}{c}\text { Cronbach's } \\
\text { Alpha }\end{array}$ & $\begin{array}{l}\text { Cronbach's } \\
\text { Alpha Based } \\
\text { on } \\
\text { Standardized } \\
\text { Items }\end{array}$ & $\mathrm{N}$ of Items \\
\hline .769 & .767 & 4 \\
\hline
\end{tabular}

Figure 2. Validity and reliability of Inaccessibility of Information Subscale

Cronbach's Alpha value of the "Inaccessibility of Information" subscale consisting of items 1-2-3-4 was found 0.769 .

ii) To Give Up Comfort Subscale 


\section{Reliability Statistics}

\begin{tabular}{|c|c|r|}
\hline $\begin{array}{c}\text { Cronbach's } \\
\text { Alpha }\end{array}$ & $\begin{array}{c}\text { Cronbach's } \\
\text { Alpha Based } \\
\text { on } \\
\text { Standardized } \\
\text { Items }\end{array}$ & N of Items \\
\hline .794 & .794 & 5 \\
\hline
\end{tabular}

Figure 3. Validity and reliability of the comfort relief subscale

The Cronbach's Alpha value of the "To Give up Comfort" subscale consisting of items 5-6-7-8-9 was found to be 0.794 .

iii) Inability to Communicate Subscale

\section{Reliability Statistics}

\begin{tabular}{|c|c|c|}
\hline $\begin{array}{c}\text { Cronbach's } \\
\text { Alpha }\end{array}$ & $\begin{array}{l}\text { Cronbach's } \\
\text { Alpha Based } \\
\text { on } \\
\text { Standardized } \\
\text { Items }\end{array}$ & $\mathrm{N}$ of Items \\
\hline 921 & 921 & 6 \\
\hline
\end{tabular}

Figure 4. Validity and reliability of inability to communicate subscale

The Cronbach's Alpha value of the "Inability to Communicate" subscale consisting of 10-11-12-13-14-15 items was found to be 0.921 .

iv) Losing Online Connection Subscale

Reliability Statistics

\begin{tabular}{|c|c|c|}
\hline $\begin{array}{c}\text { Cronbach's } \\
\text { Alpha }\end{array}$ & $\begin{array}{l}\text { Cronbach's } \\
\text { Alpha Based } \\
\text { on } \\
\text { Standardized } \\
\text { Items }\end{array}$ & $\mathrm{N}$ of Items \\
\hline .880 & .880 & 5 \\
\hline
\end{tabular}

Figure 5. Validity and reliability of losing online connection subscale

Cronbach's Alpha value of "Losing Online Connection" subscale consisting of items 16-17-18-19-20 was found 0.880 .

3.1.2 Relationships between Demographic Findings and Turkish Nomophobia Scale

Summary statistics are given for the total scores obtained in the table below. The Turkish Nomophobia Scale Average total score is 73.4583 . This indicates that the group of 408 people has an average level of nomophobia on average. In the table below, the statistical distribution of the nomophobia level of the individuals is given. 
Table 1. Statistical distribution of nomophobia level of persons

\begin{tabular}{llll}
\hline & Frequency & Percentage (\%) & Cumulative Percentage (\%) \\
\hline NMP-Q Score $=20$ & 0 & 0 & 0 \\
$21 \leq$ NMP-Q Score $<60$ & 123 & 30.1 & 30.1 \\
$60 \leq$ NMP-Q Score $<100$ & 227 & 55.6 & 85.7 \\
$100 \leq$ NMP-Q Score $\leq 1400$ & 58 & 14.3 & 100.0 \\
\hline
\end{tabular}

It was observed that 123 of the 408 (30.1\%) individuals participating in the study had mild nomophobia, 227 $(55.6 \%)$ individuals had moderate nomophobia and 58 (14.3\%) individuals had excessive nomophobia.

The tables below contain summary statistics for the 20 -item scale and its subscales for each variable.

Table 2. Statistics of nomophobia scale and its subscales

\begin{tabular}{llllll}
\hline & Minimum & Maximum & Average & SD & Skewness \\
\hline Turkish Nomophobia Scale & 27 & 139 & 73.4583 & 24.4095 & 0.212 \\
Inability to Access Information & 4 & 28 & 16.5172 & 5.9452 & 0.012 \\
To Give Up Comfort & 5 & 35 & 17.9093 & 7.7077 & 0.321 \\
Inability to Communicate & 6 & 42 & 24.8971 & 10.2460 & -0.120 \\
Losing Online Connection & 5 & 35 & 14.1348 & 7.7188 & 0.777 \\
\hline
\end{tabular}

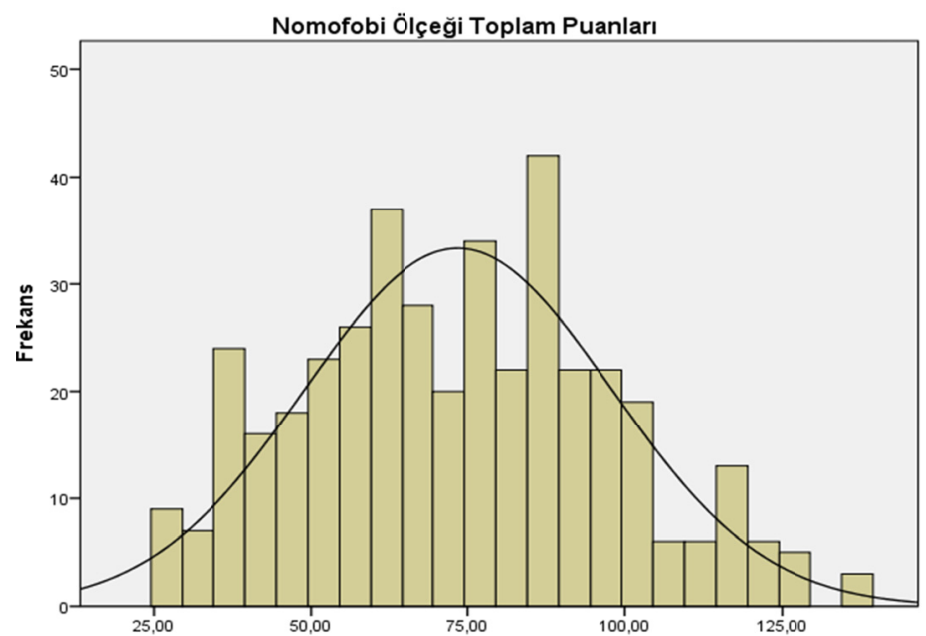

Figure 6. Total score of nomophobia scale

\subsection{5-Factor Personality Scale}

\section{Reliability Statistics}

\begin{tabular}{|c|c|r|}
\hline & $\begin{array}{c}\text { Cronbach's } \\
\text { Alpha Based } \\
\text { on } \\
\text { Alpha }\end{array}$ & \\
\hline 801 & $\begin{array}{c}\text { Standardized } \\
\text { Items }\end{array}$ & N of Items \\
\hline .798 & 85 \\
\hline
\end{tabular}

Figure 7 . Validity and reliability of the 5 -factor personality scale

Cronbach's Alpha value of 5-Factor Personality Scale applied to 408 people and consist of 85 items was found to be 0.801 . 


\section{Findings}

Table 3. Data distribution by demographic features

\begin{tabular}{|c|c|c|c|}
\hline Group & Frequency & Percentage $(\%)$ & Cumulative Percentage (\%) \\
\hline \multicolumn{4}{|r|}{ 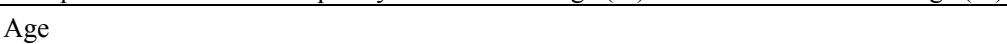 } \\
\hline$\leq 19$ & 28 & 6.9 & 6.9 \\
\hline $20-23$ & 345 & 84.6 & 91.5 \\
\hline $24-29$ & 21 & 5.1 & 96.6 \\
\hline$\geq 30$ & 14 & 3.4 & 100.0 \\
\hline Total & 408 & 100 & \\
\hline \multicolumn{4}{|l|}{ Gender } \\
\hline Male & 273 & 66.9 & 66.9 \\
\hline Female & 135 & 33.1 & 100.0 \\
\hline Total & 408 & 100 & \\
\hline \multicolumn{4}{|l|}{ Department } \\
\hline Tech. Fac. & 217 & 53.2 & 53.2 \\
\hline Sport Fac. & 191 & 46.8 & 100.0 \\
\hline Total & 408 & 100 & \\
\hline \multicolumn{4}{|c|}{ Telephone Usage by Years } \\
\hline 1-3 Year & 41 & 10.1 & 10.1 \\
\hline 4-6 Year & 127 & 31.1 & 41.2 \\
\hline 7-9 Year & 117 & 28.7 & 69.9 \\
\hline $10+$ Year & 123 & 30.1 & 100.0 \\
\hline Total & 408 & 100 & \\
\hline \multicolumn{4}{|c|}{ Daily Smartphone Usage Time } \\
\hline 1-3 Hour & 129 & 31.6 & 31.6 \\
\hline 4-6 Hour & 215 & 52.7 & 84.3 \\
\hline 7-9 Hour & 52 & 12.7 & 97.0 \\
\hline 10+ Hour & 12 & 3.0 & 100.0 \\
\hline Total & 408 & 100 & \\
\hline \multicolumn{4}{|c|}{ Mobile Internet Usage Time } \\
\hline Less than 1 year & 20 & 4.9 & 4.9 \\
\hline $1-2$ Year & 48 & 11.8 & 16.7 \\
\hline 3-4 Year & 131 & 32.1 & 48.8 \\
\hline $5+$ Year & 209 & 51.2 & 100.0 \\
\hline Total & 408 & 100 & \\
\hline \multicolumn{4}{|c|}{ Daily Mobile Internet Usage Time } \\
\hline Less than 1 Hour & 33 & 8.1 & 8.1 \\
\hline $1-2$ Hour & 173 & 42.4 & 50.5 \\
\hline 3-4 Hour & 133 & 32.6 & 83.1 \\
\hline $5+$ Hour & 69 & 16.9 & 100.0 \\
\hline Total & 408 & 100 & \\
\hline \multicolumn{4}{|c|}{ Smartphone Night Off Status } \\
\hline Evet & 38 & 9.3 & 9.3 \\
\hline Hayır & 370 & 90.7 & 100.0 \\
\hline Total & 408 & 100 & \\
\hline \multicolumn{4}{|c|}{ Time spent with friends during the day } \\
\hline Less than 1 Hour & 23 & 5.6 & 5.6 \\
\hline 1-2 Hour & 73 & 17.9 & 23.5 \\
\hline 3-4 Hour & 164 & 40.2 & 63.7 \\
\hline $5+$ Hour & 148 & 36.3 & 100.0 \\
\hline Total & 408 & 100 & \\
\hline
\end{tabular}

Note. Among 408 participants in the study.

- 28 (6.9\%) participants are between 0 and 19 years old, 345 (84.6\%) participants are between 20 and 23 years old, $21(5.1 \%)$ participants are between 24 and 29 years old, and 14 (3.4\%) participants are 30 or older age,

- 273 (66.9\%) participants are men and 135 (33.1\%) participants are women,

- 217 (53.2\%) of them are Faculty of Technology, 191 (46.8\%) of them are Faculty of Sports, 
- 41 (10.1\%) participants use the phone for 1-3 years, 127 (31.1\%) participants use the phone for 4-6 years, 117 (28.7\%) participants use the phone for 7-9 years and 123 (30.1\%) participants use the phone for 10 years or have been using the phone for longer,

- $129(31.6 \%)$ participants' daily smartphone usage time is between 1-3 hours, 215 (52.7\%) participants' daily smartphone usage time is between 4-6 hours, $52(12.7 \%)$ participants' daily smartphone usage time is between 7-9 hours and, 12 (3.0\%) participants' daily smartphone usage time is 10 hours or more,

- 20 (4.9\%) participants'mobile internet usage period is less than 1 year, 48 (11.8\%) participants'mobile internet usage period is between 1-2 years, 131 (32.1\%) participants'mobile internet usage period is between 3-4 years and, $209(51.2 \%)$ participants'mobile internet usage period 5 years more,

- $33(8.1 \%)$ participants' daily mobile internet usage time is less than 1 hour, 173 (42.4\%) participants' daily mobile internet usage time is between 1-2 hours, $133(32.6 \%)$ participants' daily mobile internet usage time is between 3-4 hours and 69 (16.9\%) participants' daily mobile internet usage time is 5 hours or more,

- 38 (9.3\%) participants turn off their smart phones at night, $370(90.7 \%)$ do not turn off their smart phones at night,

- 23 (5.6\%) participants spend less than 1 hour with friends during the day, 73 (17.9\%) participants spend time between 1-2 hours, 164 (40.2\%) participants spend time between 3-4 hours, 148 (36.3\%) participants spend 5 hours or more.

Table 4. Findings related to nomophobia scores according to participants' age, gender, department, phone usage by years, daily smartphone usage time, mobile internet usage time, daily mobile internet usage time, Smartphone night off status, time spent with friends during the day

\begin{tabular}{lllll}
\hline & $\begin{array}{l}\text { Inability to Access } \\
\text { Information }\end{array}$ & $\begin{array}{l}\text { To Give Up } \\
\text { Comfort }\end{array}$ & $\begin{array}{l}\text { Inability to } \\
\text { Communicate }\end{array}$ & $\begin{array}{l}\text { Losing Online } \\
\text { Connection }\end{array}$ \\
\hline Age & 0.562 & 0.430 & 0.167 & 0.061 \\
Total Score & 0.136 \\
Gender & 0.586 & 0.006 & 0.001 & 0.560 \\
Department & 0.018 & 0.022 & 0.206 & 0.002 \\
Phone Usage by Years & 0.009 & 0.296 & 0.006 & 0.079 \\
Daily Smartphone Usage Time & 0.537 & 0.000 & 0.000 & 0.018 \\
Mobile Internet Usage Time & 0.885 & 0.819 & 0.042 & 0.034 \\
Daily Mobile Internet Usage Time & 0.038 & 0.000 & 0.000 & 0.000 \\
Smartphone Night off Status & 0.574 & 0.005 & 0.702 & 0.000 \\
Time Spent with Friends During the Day & 0.017 & 0.185 & 0.364 & 0.377 \\
\hline
\end{tabular}

In the table above, there are p-value (Sig.) Values obtained using one-way ANOVA, where we will interpret whether each subscale and overall scale contain statistically significant differences according to demographic findings. If $\mathrm{p}$-value (Sig.) value is less than or equal to 0.05 , it shows significant difference.

There was no significant relationship between the nomophobia levels of the participants and their ages.

The gender variable has no effect on the "inability to access information" and "losing online connection" subscales. There are significant differences in "to give up comfort", "inability to communicate" subscales and overall scale. Among 3, women had higher levels of nomophobia than men.

For the "inability to access information" subscale, the nomophobia level of the technology faculty was higher. The average nomophobia scores of the sports faculty were higher for the "to give up comfort" subscale. The faculty does not have an impact on the "inability to communicate" subscale. The nomophobia level is higher in the sports faculty for the "losing online connection" subscale. Looking at the general scale of 20 items, it was observed that the faculty (department) had no effect on the total nomophobia scores.

The use of telephones by years in Turkish nomophobia scale subscales has very variable effects. However, when we look at the general scale, it was concluded that people with a phone use period of $1-3$ years have a lower nomophobia level than those with a longer phone use period.

Except for the "inaccessibility of information" subscale, "daily smartphone usage time" has an effect on all subscales and overall scale. It is observed that the nomophobia level increases as the daily smart phone usage time increases for the "to give up comfort" subscale. For the "inability to communicate" subscale, users who use $10+$ hours of daily smartphones have the lowest nomophobia. Considering the mean scores of "losing online 
connection" subscale, the lowest nomophobia level was observed in those who use smartphones for 1-3 hours daily. Again, on a general scale, it was observed that those who use smartphones daily for 1-3 hours have a lower nomophobia level than those who use more.

It was observed that "mobile internet usage time" has no effect on "inability to access information" and "to give up comfort" subscales. It is observed that as the duration of mobile internet usage increases, the total scores of the "inability to communicate" subscale increase. It was observed that total "losing online connection" total nomophobia scores are lower in those who use mobile internet for less than 1 year compared to those who use more. The duration of mobile internet usage has no effect on the general nomophobia levels of individuals.

There is a fully proportional relationship between "daily mobile internet usage time" and nomophobia level. For all subscales and the 20 -item general scale, it was observed that the level of nomophobia increased as the daily mobile internet usage time increased.

It was observed that the total scores of the "To give up Comfort" subscale were lower in those who turned off their smartphones at night. Whether turning off the smartphone at night has no effect on other subscales and the overall scale.

It was observed that the total scores of the "inability to access information" subscale were lower in those who spend time with friends during 5+ hours of day than those who spend less time with friends. The time spent with friends during the day has no effect on other subscales and the overall scale.

\section{The Relationship Between Turkish Nomophobi Scale and 5-Factor Personality Scale}

Pearson correlation coefficient was used to investigate the relationship between nomophobia level and personality. The Pearson Correlation coefficient takes values ranging from -1 to +1 . A positive value indicates the same directional relationship between the two variables, and a negative value indicates an inverse relationship between the two variables. As the correlation value gets closer to -1 and +1 , the severity of the relationship between them increases. A correlation coefficient of 0 indicates that there is no relationship between the two variables. As you get closer to 0 , the severity of the relationship decreases. The degree of dependence between the total scores of 408 people from the nomophobia level and its subscales as well as the 5-factor personality scale are given in the tables below. Values in the cell show the correlation coefficient between the two variables, and the value in parentheses shows the $p$ value. A $p$ value of less than 0.05 indicates a significant relationship between the two variables.

Table 5. The relationship among the subscales of nomophobia level

\begin{tabular}{lllll}
\hline & $\begin{array}{l}\text { Inability to Access } \\
\text { Information }\end{array}$ & $\begin{array}{l}\text { To Give up } \\
\text { Comfort }\end{array}$ & $\begin{array}{l}\text { Inability to } \\
\text { Communicate }\end{array}$ & $\begin{array}{l}\text { Losing Online } \\
\text { Connection }\end{array}$ \\
\hline Inability to Access Information & 1.000 & 0.415 & 0.466 & 0.319 \\
& & $(0.000)$ & $(0.000)$ & $(0.000)$ \\
To Give up Comfort & 0.415 & 1.000 & 0.548 & 0.458 \\
& $(0.000)$ & & $(0.000)$ & $(0.000)$ \\
Inability to Communicate & 0.466 & 0.548 & 1.000 & 0.452 \\
& $(0.000)$ & $(0.000)$ & & $(0.000)$ \\
Losing Online Connection & 0.319 & 0.458 & 0.452 & 1.000 \\
& $(0.000)$ & $(0.000)$ & $(0.000)$ & \\
\hline
\end{tabular}

A significant relationship was found among the subscales of the Turkish Nomophobia Scale. For all bilateral relations, $p$ value was found to be 0.000 . According to the results obtained, it was found statistically significant that the total scores of the subscales were all in the same direction with each other. While one decreases, the other decreases or one increases while the other increases.

Table 6. The relationship between total scores of Turkish nomophobia scale and total scores of 5-factor personality scale

\begin{tabular}{lll}
\hline & Nomophobia & Personality \\
\hline Nomophobia & 1.000 & -0.197 \\
& & $(0.000)$ \\
Personality & -0.197 & 1.000 \\
& $(0.000)$ & \\
\hline
\end{tabular}


A statistically significant inverse relation was found between the nomophobia levels of the individuals and the total scores of the 5-factor personality scale. According to the results obtained, as the nomophobia levels of the individuals increase, the total scores of the 5 -factor personality scale decrease.

\section{Discussion and Conclusion}

Within the scope of the research, after the nomophobia levels of university students were measured, the relationship of personality with the nomophobia level was examined. Discussions and conclusions about the research findings are given below.

No significant relation was found between the nomophobia levels and the ages of the subscales $(p>.05)$. It is observed that the nomophobia scores of university students in Öz and Tortop's (2018) study did not differ according to age factor. In the study of Erdem et al. (2017), it was determined that there was a contradictory and significant relationship between age and nomophobia. Bianchi and Philips (2005) determined that nomophobia is seen more frequently in young users. Both the supporting and non-supporting studies have been reached in the scope of our study. In our study, we can say that the reason for not differing is that individuals of all ages have nomophobia, that is, the same feeling and thought.

The gender variable has no effect on "inability to access information" and "losing online connection" subscales $(p>.05)$. There are significant differences in "to give up comfort", "inability to communicate" subscales and overall scale. Among 3, women had higher levels of nomophobia than men ( $<$.05). Arpaci et al. (2017), Erdem et al. (2017), SecurEnvoy (2012), Tavolacci et al. (2015), Yildirim et al. (2016) and Pavithra and Madhukumar (2015) found that women had a higher rate of nomophobia than men in their study. The studies we did are supported by other studies. The subscales of the studies we did do not overlap with some studies. We think that the reason why nomophobia is higher in women compared to men is because women can get worse and anxious faster when they cannot reach anything.

For the inability to access information subscale, the nomophobia level of students in the technology faculty was higher $(\mathrm{p}<.05)$. The average nomophobia scores of the students in the sports faculty were higher for the "to give up comfort" subscale $(\mathrm{p}<.05)$. The faculty has no effect on "inability to communicate" subscale $(\mathrm{p}>.05)$. The nomophobia level is higher for students in the sports faculty for the "losing online connection" subscale $(\mathrm{p}>.05)$. When looking at the general scale, it was seen that the faculty (department) had no effect on the total nomophobia scores $(\mathrm{p}>.05)$. We can say that the reason why the inability to access information is higher in the technology faculty is that individuals studying in the faculty of technology are more closely related to the technology. We think that giving up comfort in sports faculties causes some undesired effects such as addiction or restlessness because not looking at the phone or not entering to the internet causes negative results in individuals. Wherever the individual is, s/he must break his/her comfort and access the internet or phone. Looking at the general scale, it was seen that the faculty (department) had no effect on the total nomophobia scores. Öz and Tortop (2018) determined that nomophobia levels of students studying in different departments at the university are same. We can say that the irrational fear and anxiety experienced by individuals in both departments when they cannot access their mobile devices or cannot communicate via mobile devices or access to the Internet. Findings to support the study we have done have been reached.

"Telephone use by years" in Turkish nomophobia scale subscales creates very variable uses. But looking at the overall scale "The phone usage time" is $1-3$ years, while the phone usage time has a lower nomophobia level than those with more. Nomophobia refers to contact discomfort, anxiety, irritability or pain with a mobile phone (Pavithara et al., 2015). The number of nomophobia increases as the phone usage time increases. As the usage of the phone increases, we can say that the addiction of individuals to the phone increases. Now, over the years, we see the phone as an integral part of the body. The findings that support our study could not be reached.

"Daily smartphone usage time" has an effect on all sub-scales except inability to access information" and on the general scale. It is observed that the nomophobia level increases as the daily smart phone usage time increases for the "to give up comfort subscale". For the "inability to communicate" subscale, users who use smartphones for 10+ hours of daily have the lowest nomophobia. Considering the mean scores of "losing online connection" subscale, the lowest nomophobia level was observed in those who use smartphones for 1-3 hours daily. Also, on a general scale, it was observed that those who use smartphones daily for 1-3 hours have a lower monophobia level than those who use more $(\mathrm{p}<.05)$. Accordingly, as individuals' smartphone usage increases, their nomophobia levels increase as well. As a result, as daily phone usage time decreases, nomophobia level decreases. We can say that nomophobia has an effect on daily phone usage.

It was observed that the mobile internet usage time has no effect on the "inability to access information" and "to give up comfort" subscales ( $p>.05)$. It is seen that as mobile internet usage time increases, the total scores of the 
"inability to communicate" subscale increase. Also, it was observed that "losing online connection" total nomophobia scores were lower in those who use mobile internet for less than 1 year than those who use more (p $<.05$ ). The mobile internet usage time has no effect on the general nomophobia levels of individuals. It was observed that there were differences on some sub-scales of the scales while there weren't any differences on the others. Accordingly, we can say that individuals' mobile internet usage time is not very effective on nomophobia.

There is a fully proportional relationship between daily mobile internet usage time and nomophobia level. For all subscales and the 20-item general scale, it was observed that the level of nomophobia increased as daily mobile internet usage time inreased $(\mathrm{p}<.05)$. Kim and Koh $(2018)$ stated that individuals who isolate themselves from the outside world and who show avoidant attachment are more able to connect to their phones. For this reason, individuals who are more connected to their phone and perceive their phone as a "safe environment" may increase their nomophobia levels and show nomophobic behavior when they cannot use their smartphones or access their smartphones. Accordingly, we can say that individuals' daily mobile internet usage time is very effective on nomophobia.

It was observed that the total scores of the "to give up comfort" subscale were lower in those who turned off their smartphones at night $(p<.05)$. Whether turn off or not to turn off the smartphone at night has no effect on other subscales and overall scale $(\mathrm{p}>.05)$. We can say that nomophobia does not have an effect on the night off status of the smartphone.

It was observed that the total scores of inability to access information were lower in those who spent time with friends for $5+$ hours a day than those who spent less time with friends. The time spent with friends during the day has no effect on other subscales and overall scale $(p>.05)$. We can say that the time spent with friends during the day is not very effective on nomophobia. We can say that friendship is effective on nomophobia and that nomophobia is caused by friendlessness and loneliness.

A statistically significant inverse relation was found between the nomophobia levels of the individuals and the total scores of the 5-factor personality scale. According to the results obtained, as the nomophobia levels of the individuals increase, the total scores of the 5 -factor personality scale decrease $(\mathrm{p}<.05)$. Öz and Tortop (2018) found significant relationships between university students' nomophobia scores and five-factor personality types. In their research, Augner and Hacker (2012) stated that there is a link between problematic telephone use and psychological conditions such as mental breakdown, introversion and anxiety. We can say that personality is very effective on nomophobia. We can say that the stronger the personality of the individual, the stronger he is against nomophobia or different types of addiction.

This research can be applied to different departments with different universities as it has a limitation as a research conducted with students of Uşak University Faculty of Sport Sciences and Isparta Applied Sciences University of Technology Faculty. As the development of technology simplifies our lives and the need to add some dependencies to our lives, the need for different researches to determine the levels of nomophobia is increasing day by day. It seems that personality is effective on nomophobia. As the personality is stronger, necessary studies can be done about the personality because the level of nomophobia will decrease. If individuals have good social relationships and do not feel alone, the level of nomophobia will be low. Their dependence on technological devices will decrease.

\section{References}

Arpaci, I., Baloğlu, M., Özteke Kozan, H. İ., \& Kesici, Ş. (2017). Individual differences in the relationship between attachment and nomophobia among college students: the mediating role of mindfulness. Journal of Medical Internet Research, 19(12), 404. https://doi.org/10.2196/jmir.8847

Atasoy, B., \& Kuter, F. Ö. (2005). Küreselleşme ve spor. Uludağ Üniversitesi Ĕgitim Fakültesi Dergisi, 18(1), $11-22$.

Augner, C., \& Hacker, G. W. (2012). Associations between problematic mobile phone use and psychological parameters in young adults. International Journal of Public Health, 57(2), 437-441. https://doi.org/10.1007/s00038-011-0234-z

Başaran, İ. E. (2000). Örgütlerde Davranış. İnsanın Üretim Gücü. Feryal Matbaası. Üçüncü Basım. Ankara.

Beranuy, M., Oberst, U., Carbonell, X., \& Chamarro, A. (2009), Problematic Internet and Mobile Phone use and Clinical Symptoms in College Students: The Role of Emotional Intelligence. Computer in Human Behaviour, 25(5), 1182-1187. https://doi.org/10.1016/j.chb.2009.03.001

Bianchi, A., \& Phillips, J. G. (2005). Psychological predictors of problem mobile phone use. CyberPsychology 
and Behavior, 8(1), 39-51. https://doi.org/10.1089/cpb.2005.8.39

Erdem, H., Türen, U., \& Kalkin, G. (2017). Mobil telefon yoksunluğu korkusu (Nomofobi) yayılımı: Türkiye'den üniversite öğrencileri ve kamu çalışanları örneklemi. Bilişim Teknolojileri Dergisi, 10(1), 1-12.

Greenberg, J. (1999). Managing Behavior in Organizations (2. Basım). Prentice Hall New Jersey. ABD.

Kim, E., \& Koh, E. (2018). Avoidant attachment and smartphone addiction in college students: The mediating effects of anxiety and self-esteem. Computers in Human Behavior, 84, 264-271. https://doi.org/10.1016/j.chb.2018.02.037

King, A. L. S., Valença, A. M., Silva, A. C. O., Baczynski, T., Carvalho, M. R., \& Nardi, A. E. (2013). Nomophobia: Dependency on virtual environments or social phobia? Computers in Human Behavior, 29(1), 140-144. https://doi.org/10.1016/j.chb.2012.07.025

King, A. L. S., Valença, A. M., Sılva, A. C., Sancassıanı, F., Machado, S., \& Nardı, A. E. (2014). Nomophobia”: Impact of Cell Phone Use Interfering with Symptoms and Emotions of Individuals with Panic Disorder Compared with A Control Group. Clinical Practice \& Epidemiology in Mental Health, 10, 28-35. https://doi.org/10.2174/1745017901410010028

Mccrae, R. R., \& Costa, P. T. (1989). Reinterpreting the Myers-Briggs type indicator from the perspective of the five-factor model of personality. Journal of Personality, 57, 17-40. https://doi.org/10.1111/j.1467-6494.1989.tb00759.x

Öz, H., \& Tortop, H. S. (2018), Üniversite Okuyan Genç Yetişkinlerin Mobil Telefon Yoksunluğu Korkusu (Nomofobi) İle Kişilik Tipleri Arasındaki İlişkinin İncelenmesi. Yeni Medya Elektronik Dergisi, 2(3), 146159. https://doi.org/10.17932/IAU.EJNM.25480200.2018.2/3.146-159

Parikh, M., \& Gupta, R. (2010). Organizational Behavior. Tata Mc Graw-Hill.

Pavithra, M. B., \& Madhukumar, S. (2015). A study on nomophobia-mobile phone dependence, among students of a medical college in Bangalore. National Journal of Community Medicine, 6(3), 340-344.

Robbins, S. P., \& Judge, T. A. (2012). Örgütsel Davranış (14. Basımdan). Çeviri, Ed. İnci. Erdem, Nobel Yayıncilik.

Salehan, M., \& Negahban, A. (2013), Social Networking on Smartphones: When mobile Phones Become Addictive. Computers in Human Behavior, 29(6), 2632-2639. https://doi.org/10.1016/j.chb.2013.07.003

Secur Envoy. (2012). 66\% of the population suffer from Nomophobia the fear of being without their phone. Retrieved from https://www.securenvoy.com

Somer, O., Korkmaz, M., \& Tatar, A. (2004). Kuramdan uygulamaya beş faktör kişilik modeli ve beş faktör kişilik envanteri (5FKE). Ege Üniversitesi Edebiyat Fakültesi, Yayın No: 128, İzmir.

Tatar, A. (2005). Çok Boyutlu Kişilik Envanteri'nin Madde-Cevap Kuramına Göre Kısa Formunun Gelişstirilmesi ve Psikometrik Özelliklerinin İncelenmesi. Doktora Tezi, Ege Üniversitesi, Sosyal Bilimler Enstitüsü, İzmir.

Tavolacci, M. P., Meyrignac, G., Richard, L., Dechelotte, P., \& Ladner, J. (2015). Problematic use of mobile phone and nomophobia among French college students. The European Journal of Public Health, 25(3), 206. https://doi.org/10.1093/eurpub/ckv172.088

Tezcan, M. (1997). Eğitim sosyolojisi (Vol. 11). Ankara.

Yanbastı, G. (1990). Kişilik Kuramları (p. 53). Ege Üniversitesi, İzmir, Edebiyat Fakültesi Yayınları.

Y1ldırım, C. (2014). Exploring the dimensions of nomophobia: Developing and validating a questionnaire using mixed methods research. Graduate Theses and Dissertations.

Yıldırım, C., \& Correia, A.-P. (2015). Exploring the dimensions of nomophobia: Development and validation of a self-reported questionnaire. Computers in Human Behavior, 49, 130-137. https://doi.org/10.1016/j.chb.2015.02.059

Yıldırım, C., Sumuer, E., Adnan, M., \& Yıldırım, S. (2016). A growing fear: Prevalence of nomophobia among Turkish College Students. Information Development, 32(5), 1322-1331. https://doi.org/10.1177/0266666915599025

Yıldırım, D., Yıldırım, E., Ramazanoğlu, F., Uçar, Ü., Tuzcuoğulları, T., \& Demirel, E. T. (2006). Üniversite Öğrencilerinin Spora Bakış Açıları ve Spor Yapma Durumu. Fırat Üniversitesi Doğu Araştırmaları Dergisi, 4(3), 49-53. 


\section{Copyrights}

Copyright for this article is retained by the author, with first publication rights granted to the journal.

This is an open-access article distributed under the terms and conditions of the Creative Commons Attribution license (http://creativecommons.org/licenses/by/4.0/). 